\title{
ANALISIS RASIONALISASI ANGGARAN DAN DAMPAK ADANYA RASIONALISASI ANGGARAN TERHADAP PELAKSANAAN PROGRAM KERJA PEMERINTAH DAERAH KABUPATEN BULELENG
}

\author{
I Made Sinar Dewata Putra, I Kadek Ari Mahardika, \\ Ketut Krisnayanti, Ni Made Saniscaryani Kunti, Krisna Chiva \\ Jurusan Akuntansi, Universitas Pendidikan Ganesha, Singaraja, Bali, Indonesia
}

\begin{abstract}
Abstrak
Penelitian ini bertujuan untuk menganalisis mengenai pelaksaan rasionalisasi anggaran di kabupaten Buleleng dan bagaimana pengaruh rasionalisasi anggaran terhadap program kerja di instansi di kabupaten Buleleng. Data penelitian ini dilakukan dengan metode wawancara kepada salah satu staff bagian keuangan pada kantor DPPKBPP-PA kabupaten Buleleng dan melakukan dokumentasi. Rasionalisasi anggaran yang terjadi disetiap SKPD di Kabupaten Buleleng tidak hanya berimplikasi pada penundaan atau pembatalan program atau kegiatan yang ada pada SKPD tersebut, namun juga berimplikasi pada pengurangan anggaran operasional perkantorannya. Sehingga beberapa kegiatan dan program kerja dari instansi atau kantor dan dinas tersebut harus ditunda pelaksanaanya.
\end{abstract}

Kata kunci: Anggaran , Rasionalisasi, SKPD

\begin{abstract}
This study aims to analyze the implementation of budget rationalization in Buleleng regency and how the influence of budget rationalization on work programs in agencies in Buleleng regency. The data of this study was conducted by interviewing one of the staff of the financial section at the office of the $D P P K B P P-P A$ Buleleng regency and doing documentation. The rationalization of the budget that occurs in each SKPD in Buleleng Regency does not only have implications for the delay or cancellation of programs or activities that exist in the SKPD, but also has implications for reducing the office operational budget. So some of the activities and work programs of the agencies or offices and offices must be postponed.
\end{abstract}

Keywords : Budget, Rationalization, SKPD

\section{Pendahuluan}

Perkembangan suatu negara untuk lebih maju dilaksanakan melalui pembangunan nasional secara terus menerus dan berkesinambungan dengan tujuan meningkatkan kesejahteraan rakyat. Salah satu bagian penting dari pembangunan nasional adalah pembangunan ekonomi. Pembangunan ekonomi pada dasarnya mengoptimalkan peranan sumber daya dalam menciptakan kenaikan pendapatan pada sektor-sektor ekonomi dan mengusahakan tercapainya pertumbuhan ekonomi yang tinggi untuk meningkatkan taraf hidup dan kesejahteraan masyarakat. Pembangunan nasional yang dilaksanakan membutuhkan anggaran belanja pada setiap periode. Seiring dengan peningkatan pembangunan nasional maka anggaran belanja yang diperlukan juga semakin meningkat. Anggaran belanja tersebut dikumpulkan dari segenap potensi sumber daya dan pendapatan yang dimiliki oleh suatu daerah. Anggaran pendapatan dan belanja yang dikumpulkan dituang dalam suatu program atau rancangan pemerintah yang disebut Anggaran Pendapatan dan Belanja Daerah (APBD).

Perencanaan anggaran merupakan proses yang paling krusial dalam penyelenggaraan pemerintahan, karena berkaitan dengan tujuan dari pemerintahan itu sendiri untuk mensejahterakan rakyatnya. Perencanaan merupakan proses yang terintegrasi, oleh karenanya output dari perencanaan adalah penganggaran. Perencanaan merupakan bagian terpenting dalam kegiatan pembangunan oleh pemerintah. Dari perencanaan itu proses/kegiatan pembangunan berjalan sesuai dengan arah yang telah 
ditentukan. Oleh karena itu, tahap perencanaan menjadi pusat perhatian bagi semua pemerintah daerah dalam kegiatan pembangunan. Pengaturan pada aspek perencanaan diarahkan agar seluruh proses penyusunan APBD semaksimal mungkin dapat menunjukan latar belakang pengambilan keputusan dalam penetapan arah kebijakan umum, skala proritas dan penetapan alokasi serta distribusi sumber daya dengan melibatkan partisipasi masyarakat. Dokumen Pelaksanaan Anggaran yang disampaikan oleh masing-masing satuan kerja perangkat daerah (SKPD) yang disusun dalam format Rencana Kerja dan Anggaran (RKA) SKPD harus betul-betul dapat menyajikan informasi yang jelas tentang tujuan, sasaran, serta korelasi antara besaran anggaran (beban kerja dan harga satuan) dengan manfaat dan hasil yang ingin dicapai atau diperoleh masyarakat dari suatu kegiatan yang dianggarkan.

Nordiawan, dkk (2012:4) menjelaskan bahwa akuntansi pemerintahan mengkhususkan dalam pencatatan dan pelaporan transaksi-transaksi yang terjadi dalam badan pemerintahan.Sadeli (2015:6) menyatakan akuntansi pemerintahan termasuk pula akuntansi lembaga-lembaga nonprofit atau institusional accounting,mengkhususkan pada masalah pencatatan dan pelaporan transaksi dari unit-unit pemerintah dan organisasi nonprofit lainnya.Akuntansi pemerintahan diatur dalam PP. No 71 Tahun 2010 tentang standar akuntansi pemerintahan. Tujuan dari Standar Akuntansi Pemerintahan adalah:

a. Standar Akuntansi Pemerintahan (SAP) adalah prinsip-prinsip akuntansi yang di terapkan dalam menyusun dan meyajikan laporan keuangan pemerintah.

b. SAP disusun dalam rangka meningkatkan transparansi dan akuntabilitas pengelolaan keuangan Negara.

c. SAP berlaku untuk pemerintah pusat dan daerah.

Budidarma (2010:20) menjelaskan anggaran berasal dari kata budget (Inggris), sebelumnya dari kata bougette (Perancis) yang berarti "sebuah tas kecil". Anggaran dalam arti luas meliputi jangka waktu anggaran direncanakan, dilaksanakan dan dipertanggungjawabkan. Anggaran dalam arti sempit meliputi rencana penerimaan dan pengeluaran dalam satu tahun saja. Penganggaran (budgeting) merupakan aktivitas mengalokasikan sumberdaya keuangan yang terbatas untuk pembiayaan belanja organisasi yang cenderung tidak terbatas. Anggaran sektor publik adalah rencana kegiatan dan keuangan periodik (biasanya dalam periode tahunan) yang berisi program dan kegiatan dan jumlah dana yang diperoleh (penerimaan/pendapatan) dan dibutuhkan (pengeluaran/ belanja) dalam rangka mencapai tujuan organisasi.

Keuangan Daerah menurut abdul halim (2012:43) yaitu proses pengidentifikasian, pengukuran, pencatatan, dan pelaporan transaksi ekonomi (keuangan) dari entitas pemerintah daerah (kabupaten, kota, atau provinsi) yang dijadikan sebagai informasi dalam rangka pengambilan keputusan ekonomi oleh pihak-pihak eksternal entitas pemerintah daerah (kabupaten, kota, atau provinsi) yang memerlukan.

Pengelolaan keuangan daerah adalah keseluruhan kegiatan yang meliputi perencanaan, pelaksanaan, penatausahaan, pelaporan dan pertanggungjawaban, pengawasan daerah". Pengelolaan keuangan daerah dalam hal ini megandung beberapa kepengurusan dimana kepengurusan umum atau yang sering disebut pengurusan administrasi dan kepengurusan khusus atau juga sering disebut dengan pengurusan bendaharawan. .Kinerja merupakan suatu konstruk multidimensional yang mencakup banyak faktor yang mempengaruhinya baik di sektor publik maupun di suatu perusahaan yang mana kinerja ini sangat penting dalam berbagai kegiatan apapun.

Tujuan pengukuran kinerja sektor publik yaitu untuk memperbaiki kehidupan masyarakat dengan cara memberikan pelayanan terbaik yang hal itu seringkali sulit diukur dengan ukuran finansial. Pengukuran kinerja meliputi aktivitas penetapan serangkaian ukuran atau indikator kinerja yang memberikan informasi sehingga memungkinkan bagi unit kerja sektor publik untuk memonitor kinerjanya dalam menghasilkan output dan outcome terhadap masyarakat.

Anggaran Pendapatan dan Belanja Daerah Berdasaran Pasal 64 ayat (2) UndangUndang Nomor 5 Tahun 1974 tentang PokokPokok Pemerintahan di Daerah, APBD dapat didefinisikan sebagai rencana operasional keuangan pemerintah daerah, dimana di satu 
pihak menggambarkan perkiraan pengeluaran setinggi-tingginya guna membiayai kegiatankegiatan dan proyek-proyek daerah dalam 1 tahun anggaran tertentu, dan di pihak lain menggambarkan perkiraan penerimaan dan sumber-sumber penerimaan daerah guna menutupi pengeluaran-pengeluaran dimaksud (Mamesah, 1995:20).

Rasionalisasi anggaran secara umum diatur dalam peraturan pemerintah No. 58 tahun 2005 tentang pengelolaan keuangan daerah. Dengan menerapkan konsep otonomi daerah, semua program yang berhubungan dengan daerah telah diserahkan secara penuh oleh pemerintah pusat kepada pemerintah daerah. Maka kemudian menjadi tanggung jawab pemerintah daerah bersama anggota legislatif menguatkannya dalam bentuk perda.

Pemerintah kabupaten Buleleng saat ini tengah melaksanakan sebuah program baru mengenai penghematan penggunaan anggaran. Program ini sering kita kenal dengan rasionalisasi anggaran. Yang mana dengan rasionalisasi ini, diharapkan pemerintah setempat mampu mengurangi pagu anggaran di setiap dinas dengan meniadakan program kerja yang telah dicanangkan atau tetap mengadakannya dengan menggeser ke pos anggaran yang ada. Sehingga dengan kebijakan atau program baru ini, pemerintah setempat harus beradaptasi lagi agar dapat melaksanakan setidaknya $90 \%$ program kerja yang telah dicanangkan. Belum lagi jika ada kegiatan kegiatan besar di wilayah kabupaten maka pemerintah kabupaten akan memotong dana per SKPD di masing-masing dinas. Hal ini tentu akan mempengaruhi beberapa kegiatan yang seharusnya dilaksanakan.

Berdasarkan permasalahan diatas, adapun rumusan masalah yang dilakukan yaitu bagaimana analisis mengenai pelaksaan rasionalisasi anggaran di kabupaten Buleleng dan bagaimana pengaruh rasionalisasi anggaran terhadap program kerja di instansi di kabupaten Buleleng.

\section{Metode}

Untuk menganalisis dan menggambarkan secara lebih dalam mengenai rasionalisasi anggaran, kami melakukan wawancara kepada salah satu staff bagian keuangan pada kantor DPPKBPP-PA kabupaten Buleleng. Dan untuk menunjang informasi yang telah kami dapat melalui proses wawancara, kami melakukan metode dokumentasi. Metode dokumentasi merupakan teknik pengumpulan data yang tidak langsung ditujukan kepada subjek penelitian. Metode ini dilakukan dengan mencatat atau mengumpulkan data-data yang tercantum pada website resmi dan didapat dari jurnal jurnal yang membahas topik yang sama.

\section{Hasil dan Pembahasan}

Prinsip-prinsip dasar (azas) yang berlaku di bidang pengelolaan Anggaran Daerah yang berlaku juga dalam pengelolaan Anggaran Negara / Daerah sebagaimana bunyi penjelasan dalam Undang Undang No. 17 Tahun 2003 tentang Keuangan Negara dan Undang-Undang Nomor 1 Tahun 2004 tentang Perbendaharaan Negara, yaitu :

1. Kesatuan, azas ini menghendaki agar semua Pendapatan dan Belanja Negara/Daerah disajikan dalam satu dokumen anggaran.

2. Universalitas, azas ini mengharuskan agar setiap transaksi keuangan ditampilkan secara utuh dalam dokumen anggaran.

3. Tahunan, azas ini membatasi masa berlakunya anggaran untuk suatu tahun tertentu.

4. Spesialitas, azas ini mewajibkan agar kredit anggaran yang disediakan terinci secara jelas peruntukannya.

5. Akrual, azas ini menghendaki anggaran suatu tahun anggaran dibebani untuk pengeluaran yang seharusnya dibayar, atau menguntungkan anggaran untuk penerimaan yang seharusnya diterima, walaupun sebenarnya belum dibayar atau belum diterima pada kas.

6. Kas, azas ini menghendaki anggaran suatu tahun anggaran dibebani pada saat terjadi pengeluaran/ penerimaan uang dari/ ke kas daerah.

Pemerintah daerah diberi kewenangan untuk mengatur dan mengurus sendiri urusan pemerintahan menurut asas ekonomi dan tugas berbantuan sesuai dengan: 
a) Undang-Undang Nomor 32 tahun 2004 tentang Pemerintahan Daerah atau yang baru Undang-Undang Nomor 23 Tahun 2014 Tentang Pemerintahan Daerah,

b) Undang-Undang Nomor 33 Tahun 2004 tentang Perimbangan Keuangan antara Pemerintah Pusat dan Daerah Anggaran Pendapatan dan Belanja Daerah yang disingkat APBD,

c) Undang-Undang Nomor 17 Tahun 2003 Tentang Keuangan Negara, dan

d) Undang-Undang Nomor 1 Tahun 2004 tentang Perbendaharaan Negara

Kebijakan Umum Anggaran (KUA) menjadi acuan dalam perencanaan operasional anggaran. Kebijakan anggaran berkaitan dengan analisa fiskal sedangakan operasional anggaran berkaitan dengan sumber daya. Menurut Peraturan Menteri Dalam Negeri No 22 Tahun 2011 KUA mencakup hal-hal yang sifatnya kebijakan umum dan tidak menjelaskan hal-hal yang bersifat teknis. Hal-hal yang sifatnya kebijakan umum, seperti:

a. Gambaran kondisi ekonomi makro termasuk perkembangan indikator ekonomi makro daerah;

b. Asumsi dasar penyusunan Rancangan APBD Tahun Anggaran termasuk laju inflasi, pertumbuhan PDRB dan asumsi lainnya terkait dengan kondisi ekonomi daerah;

c. Kebijakan pendapatan daerah yang menggambarkan prakiraan rencanasumber dan besaran pendapatan daerah untuk tahun anggaran serta strategi pencapaiannya;

d. Kebijakan belanja daerah yang mencerminkanprogram dan langkah kebijakan dalam upaya peningkatan pembangunan daerah yang merupakan manifestasi dari sinkronisasi kebijakan antara pemerintah daerah dan pemerintah serta strategi pencapaiannya;

e. Kebijakan pembiayaanyang menggambarkan sisi defisit dan surplus anggaran daerah sebagai antisipasi terhadap kondisi pembiayaan daerah dalam rangka menyikapi tuntutan pembangunan daerah serta strategi pencapaiannya. (Peraturan Menteri Dalam Negeri No 22 th 2011).

Sumber-sumber penerimaan daerah dalam pelaksanaan desentralisasi di Kabupaten Buleleng terdiri dari :

1. Pendapatan asli daerah (PAD) adalah penerimaan yang diperoleh dari pungutanpungutan daerah berupa :

- Pajak daerah.

- Retribusi daerah.

- Hasil pengolahan kekayaan daerah.

- Keuntungan dari perusahaan-perusahaan milik daerah.

- Lain-lain PAD.

2. Dana perimbangan. adalah dana yang dialokasikan dari APBN untuk daerah sebagai pengeluaran pemerintah pusat untuk belanja daerah, yang meliputi :

- Dana bagi hasil yaitu dana yang berasal dari APBN yang dialokasikan kepada daerah sebagai hasil dari pengelolaan sumber daya alam didaerah oleh pemerintah pusat.

- Dana alokasi umum yaitu dana yang berasal dari APBN yang dialokasikan kepada daerah dengan tujuan sebagai wujud dari pemerataan kemampuan keuangan antara daerah.

- Dana alokasi khusus.yaitu dana yang bersumber dari APBN yang dialokasikan kepada daerah tertentu dengan tujuan untuk mendanai kegiatan khusus daerah yang disesuaikan dengan prioritas nasional.

- Pinjaman daerah.

- Penerimaan lain-lain yang sah, berupa:

a. Penjualan kekayaan daerah yang tidak dipisahkan, jasa giro dan pendapatan bunga.

b. Keuntungan selisih nilai tukar rupiah terhadap mata uang asing.

Komisi, penjualan, ataupun bentuk lain sebagai akibat dari penjualan dan pengadaan barang atau jasa oleh daerah kecenderungan semakin meningkatnya kebutuhan anggaran belanja daerah Kabupaten Buleleng tidak berbanding lurus dengan 
peningkatan anggaran pendapatan daerah, kemampuan riil pendapatan daerah pada beberapa tahun terkhir cenderung semakin menurun. Sehingga untuk mengatasi hal tersebut pemerintah setempat melakukan rasionalisasi anggaran guna melkaukan penghematan anggaran yang ada di kabupaten. Pemerintah provinsi Bali mengurangi pencairan dana bagi hasil pajak dan bantuan keuangan khusus (BKK) tahun 2019, dengan total 14,177 miliar. Yang mana hal ini tentu mempengaruhi Anggaran Pendapatan Belanja (APBD) di Kabupaten Buleleng di Induk 2019. Sehingga APBD di Induk ini harus di rombak agar tidak menggunakan anggaran daerah terlalu banyak. Data dihimpun, dalam APBD Induk 2019, pemkab Buleleng telah mengalokasikan dana bagi hasil pajak dari Pemerintah provinsi Bali sebesar Rp 167 miliar. Kemudian BKK dari Pemerintah provinsi Bali dipasang sebesar Rp 173,692 miliar.

Sehingga dari hasil verifikasi, Pemerintah provinsi Bali pun mengurangi kucuran dana bagi hasil pajak menjadi sebesar Rp 156 miliar, atau berkurang sebanyak Rp 10,543 miliar. Sedangkan untuk BKK Pemerintah provinsi Bali mengurangi sebesar Rp 170 miliar, atau berkurang sebesar Rp 3,6 miliar. Dari dua sumber tersebut total pengurangan APBD induk 2019 menjadi sebesar Rp 14,177 miliar.

Rasionalisasi anggaran yang terjadi disetiap SKPD di Kabupaten Buleleng tidak hanya berimplikasi pada penundaan atau pembatalan program atau kegiatan yang ada pada SKPD tersebut, namun juga berimplikasi pada pengurangan anggaran operasional perkantorannya. Sehingga beberapa kegiatan dan program kerja dari instansi atau kantor dan dinas tersebut harus ditunda pelaksanaanya.

Upaya Pemerintah Kabupaten Buleleng dalam mengatasi rasionalisasi anggaran pendapatan dan belanja daerah tahun 2017 adalah bertujuan untuk meningkatkan atau memulihkan kondisi pendapatan daerah guna menghindari implikasi pada stagnasi pembangunan daerah tahun berikutnya yakni tahun anggaran 2018. Sebagaimana seperti halnya yang telah terjadi pada tahun anggaran 2017 dimana beberapa program pembangunan daerah tidak bisa direalisasikan akibat adanya penurunan pendapatan daerah. Untuk itu diperlukan strategi kebijakan yang efektif dan efesien yang dinilai mampu memperbaiki kondisi tersebut agar pembangunan daerah Kabupaten Buleleng kedepannya dapat berjalan sesuai dengan rencana yang telah ditetapkan.

Dengan telah diterbitkannya rincian transfer ke daerah dan dan desa dalam APBN tahun anggaran 2018 dengan rincian pendapatan daerah pada rancangan APBD tahun anggran 2018 dirancang sebesar Rp 2,10 triliun lebih,jika dibandingkan dengan anggaran tahun lalu sebesar Rp 2,25 triliun lebih berarti mengalami penurunan sebesar Rp 143,95 miliar lebih atau $6,40 \%$.

Perincian PAD mengalami penurunan sebesar $\mathrm{Rp} 100,61$ miliar lebih atau $2132 \%$ penurunan ini disebabkan karena adanya pergeseran pendapatan dana BOS ke rekening hibab, dana perimbangan mengalami penurunan sebesar $\mathrm{Rp} 79,36$ miliar lebih atau $5,88 \%$ sesuai dengan rincian transfer ke daerah dan dana desa dalam APBN tahun anggaran 2018 dari Dirjen Perimbangan Keuangan.

Dan lain-lain pendapatan daerah yang sah mengalami peningkatan sebesar Rp 36,02 miliar lebih atau $8,11 \%$ peningkatan ini disebabkan karena adanya pergeseran pendapatan dana BOS, peningkatan dana desa serta adanya penurunan dana desa. Belanja Daerah yang terdiri dari belanja tidak langsung dan belanja langsung pada rancangan APBD tahun anggaran 2018 dirancang sebesar Rp 2,08 triliun lebih, jika dibandingkan dengan anggaran tahun lalu sebesar Rp 2,26 triliun lebih, sehingga terjadi penurunan sebesar Rp 183,49 miliar lebih atau 8,09\%. Pembiayaan daerah pada rancangan APBD tahun anggaran 2018 yang terdiri dari penerimaan pembiayaan dan pengeluaran pembiayaan dirancang sebesar $\mathrm{Rp} 22$ miliar, dengan rincian sebagai berikut: Pada Bank BPD Bali Rp 16.500.000.000, Jamkrida Rp 100.000.000, Bank Buleleng Rp 45 1.000.000.000, PDAM Rp 4.400.000.000.

Seiring dengan sedang defisitnya keuangan negara dan adanya kebijakan nasional pengurangan anggaran dari kementrian keuanga maka dampak langsung bagi kegiatan rencana dan program di daerahpun dirasakan. Setelah adanya rasionalisasi anggaran perubahan disusul dengan rasionalisasi anggaran untuk tahun 2018. Di Kabupaten Buleleng 
juga melakukan hal yang sama. Dengan harapan dapat melakukan penghematan dan menutupi kekurangan anggaran di tahun sebelumnya.

Lalu bagaiman dengan kegiatan-kegiatan yang disusun dan direncanakan sebelumnya? Pimpinan instansi tentu harus menyikapinya dengan bijak. "First think First" atau dahulukan yang utama dalam menyususun rencana anggaran 2018. Penyusunan rencana keuangan harus betul-betul yang memberikan manfaat bagi masyarakat dan lingkungan. Sekiranya bisa dilakukan satu kali untuk dua-tiga hal maka akan lebih baik dan efisien. Penyusunan rencana juga harus mengacu pada renstra, renja, dan tentunya standar pelayanan minimal yang ada. Kegiatan atau program yang bukan SPM setidaknya diurutkan dalam prioritas setelah kegiatan yang berkaitan langsung dengan SPM.

Dengan adanya rasionalisasi dari pemerintah pusat ini tentu sangat mempengaruhi program-program dari pemerintah daerah. Pembangunan infrastruktur banyak yang gagal dilakukan akibat kekurangan dana. Sehingga Pemerintah daerah kabupaten Buleleng 'terpaksa' menunda bahkan meniadakan beberapa programnya demi kelancaran pembangunan infrastruktur di daerah.

Selain itu, dampak dari rasionalisasi anggaran ini sangat dirasakan oleh instansi instansi kecil di daerah Kabupaten Buleleng. Karena instansi ini memiliki program kerja yang lebih sedikit dibanding instansi besar lainnya. Sehingga pemerintah kabupaten Buleleng pun banyak memangkas dana untuk instansi instansi kecil tersebut. Pemangkasan dana yang dilakukan mencapai Rp 200.000.000 atau sekitar 20\% dari dana yang seharusnya didapat.

\section{Simpulan dan Saran Simpulan}

Rasionalisasi anggaran secara umum diatur dalam peraturan pemerintah No. 58 tahun 2005 tentang pengelolaan keuangan daerah. Dengan menerapkan konsep otonomi daerah, semua program yang berhubungan dengan daerah telah diserahkan secara penuh oleh pemerintah pusat kepada pemerintah daerah. Maka kemudian menjadi tanggung jawab pemerintah daerah bersama anggota legislatif menguatkannya dalam bentuk perda.

Rasionalisasi anggaran yang terjadi disetiap SKPD di Kabupaten Buleleng tidak hanya berimplikasi pada penundaan atau pembatalan program atau kegiatan yang ada pada SKPD tersebut, namun juga berimplikasi pada pengurangan anggaran operasional perkantorannya. Sehingga beberapa kegiatan dan program kerja dari instansi atau kantor dan dinas tersebut harus ditunda pelaksanaanya.

\section{Saran}

Bagi pemerintah daerah diharapkan lebih bijak lagi dalam memanfaatkan anggaran yang ada agar dapat melaksanakan program kerjanya dengan baik, meskipun adanya rasionalisasi anggaran. Sehingga seluruh program kerja pemerintah khususnya pada pembangunan infrastruktur daerah dapat dirasakan oleh masyarakat. Serta lebih mengutamakan program kerja yang mampu memberikan dampak yang baik dalam jangka panjang oleh masyarakat. Dan pemerintah di kabupaten Buleleng diharapkan untuk mempertimbangkan kembali pengadaan festival seperti Bulfest, dan lain sebagainya, mengingat dana yang dikeluarkan sangat banyak. Dengan pertimbangan, pengadaan festival tersebut

\section{DAFTAR PUSTAKA}

Bactiar Arif, Muchlis dan Iskandar. 2002. Akuntansi Pemerintahan. Jakarta : Salemba Empat I. C Lontaan. S. Pangarepan. 2016. Analisis Belanja Daerah. Jurnal EMBA. 4(1):898906.

Sugiantini Ayu. 2015. Kecenderungan Dana Alokasi Khusus Kabupaten Buleleng. Jurnal Jurusan Pendidikan Ekonomi. 5(1):1-10.

Rani, Elfreda, dan Suyatin. Analisis Kinerja Anggaran dan Realisasi. https://www.google.com/url?sa=t\&source=web\&rct=j\&url=https://media.neliti.com/medi a/publications/55083-ID-analisis-kinerja-anggaran-dan-realisasi.pdf 